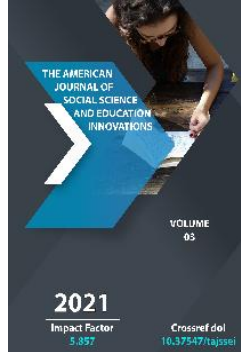

Journal Website: http://usajournalshub.c om/index,php/tajssei

Copyright: Original content from this work may be used under the terms of the creative commons attributes 4.0 licence.

\section{The Issues Of The Study Of Symbol Types}

Akhmedova Zumradkhon Sharopidinovna Teacher, Department Of “The Russian Language Methodology", Faculty Of Philology, Fergana State University, Ferghana, Uzbekistan

Davlyatova Gulchekhra Nasirovna

Candidate Of Pedagogical Sciences, Associate Professor, Department Of "Russian Philology", Faculty Of Philology, Fergana State University, Ferghana, Uzbekistan

\title{
ABSTRACT
}

The article under discussion depicts the study of symbols types in general. The authors of the article consider that in the process of human cognitive activity, symbolization manifests itself in a variety of forms. At present, as a result of the expansion and strengthening of intercultural contacts, there has been a significant increase in the sociocultural, intellectual and spiritual and creative role of symbols.

\section{KEYWORDS}

Symbol types, information, linguistics, transmit, semiotics, central object, intellect, system, properties.

\section{INTRODUCTION}

Symbols play a crucial role in the formation and development of human consciousness. "The human civilization is impossible without symbols, the human mind is inseparable from functioning of symbols, and probably in general, intellect should be identified exactly with functioning of symbols", - one of founders of modern semiotics C. Morris notes in his works [2]. 
Symbols are the object of study of many disciplines: linguistics, philosophy, culturology, psychology, anthropology, etc., but they became the central object of study in the special science of signs and symbols semiotics.

Considering a symbol in this or that field of cognition or reality, we notice that, once it has been established, we immediately see all the consequences that arise from it. Therefore, in contrast to the direct description of the elements of the concept of a symbol, we now study those sequences of meaning, which arise during the functioning of the symbol in different areas and is nothing other than the doctrine of types of symbols.

According to the Russian philosopher and philologist A.F. Losev, the doctrine of the types of symbols is the study of those semantic sequences that arise during the functioning of a symbol in various areas of human activity [1]. He distinguishes nine types of symbols, which are listed below.

- Scientific symbols (e.g., mathematical equations, rectangular triangle, etc.).

- Philosophical symbols do not differ essentially from scientific symbols, except for their ultimate generalization (for example, philosophical categories: reason, necessity, freedom, etc.).

- Artistic symbols (the image of N. Gogol's "bird-troika").

- Mythological symbols must be clearly distinguished from religious symbolism (circle, fire symbol, etc.).

- Religious symbols (the cross, the sacraments of the divine).

- Symbols shaped by nature, society, and the whole world. The deeper they are perceived and studied by man, the more they are filled with a variety of symbols, receive a variety of symbolic functions, although in themselves and objectively they are not at all only our symbols (for example, the world tree and fertility symbols).

- Human-expressive symbols. Man expresses his inner state in an outward manner, so that his appearance in one way or another is always symbolic of his inner state (a smile is a symbol of joy, a pale face is an indicator of fear). The physical features of the human body (skin color, the structure of the nose, etc.) also act as a symbol.

- Ideological and incentive symbols (Ideal, motto, plan, project, program, decision, resolution, slogan, appeal, proclamation, propaganda, agitation, poster, poster, password, nickname, decree, order, command, law, constitution, delegate, ambassador, parliamentarian).

- The external-technical symbol implements the principle of performing an endless series of actions (bows, handshakes, dance, etc.).

The Russian poet N.N. Rubtsov gives a different typology of symbols, based on the dependence on the external form or material of implementation of symbolic expression in the system of culture. He identifies five basic ways of implementing symbolic expressions, as well as various combinations [3]:

- Graphic symbols are inherent in numerous forms of human activity - art, science, politics, etc.

- Plastic symbols are found mainly in art.

- Discursive symbols are symbolic generalizations and constructions resulting not so much from visual perception as from 
the thought process. They include literary symbols and their accompanying language constructions, metaphors, comparisons, etc., as well as symbols of philosophy, theology, science, legislation, etc.

- Procedural symbols express certain values and ideas through concrete actions. These are all kinds of human political activities rituals, ceremonies, meetings, as well as various folk-calendar celebrations and rites.

- Operational symbols are used to maintain a certain social order, a stable state of society. For example, currency signs are symbols in their various "hypostases" (money, credit, etc.).

- The American sociologist William Warner, proceeding from the fact that signs can give expression to different "things" (objects, perceptions, feelings, etc.), distinguished three types of symbols: referential; evocative and intermediate [4].

- Referential symbols are referential and scientific concepts, logic of judgment, and rational discourse. The meanings of these symbols are usually stipulated in the community and their relationships are strictly fixed. They are usually used to communicate information and are verifiable.

- Evocative symbols give expression to feelings. Their meanings are expressive, affective, non-rational; they refer to feelings, ways of knowing and understanding that transcend everyday experience and are not empirically verifiable [5-7].

From Warner's point of view, these symbols play an extremely important role in preserving social life and maintaining community solidarity: people need signs "as external forms to give sensual reality to those feelings and perceptions that fill their mental life. Through evocative symbols, these weightless and elusive feelings and ideas are transferred to the world of perceived "objective reality"; a stable and stable sign medium is one of the most important mechanisms for preserving society. Most symbols appearing in everyday life belong to the intermediate type; they combine the properties of referential and evocative symbols [4].

\section{CONCLUSION}

Thus, in the process of human cognitive activity, symbolization manifests itself in a variety of forms. At present, as a result of the expansion and strengthening of intercultural contacts, there has been a significant increase in the sociocultural, intellectual and spiritual and creative role of symbols.

\section{REFERENCES}

1. Losev A. F. (1976). The Problem of the Symbol and Realistic Art. Moscow. P.67

2. Morris C. (1983). Foundations of the Theory of Signs. Semiotics. Moscow,. pp. 37-89

3. Rubtsov N.M. (1985). Essays. Miscellaneous/Symbolism in $\mathrm{N}$. Rubtsov's lyrics. Moscow. P.4

4. Warner W. (2000). The Living and the Dead. Moscow. P. 1.

5. Nasirovna, D. G., \& Numanovna, S. S. (2021). The operation of diminutives in works of art at the present stage of development of literature. Academicia: an international multidisciplinary research journal, 11(1), 1426-1430.

6. Muzaffarovna, A. N., \& Nasirovna, D. G. Reasons of new words formation in youth sociolect. Chief Editor. 
The American Journal of Social Science and Education Innovations (ISSN - 2689-100x)

Published: April 28, 2021 | Pages: 190-193

Doi : https://doi.org/10.37547/tajssei/Volumeo3Issue04-28

2021: 5.857

OCLC - 1121105668

7. Zikirov, M. C., Qosimova, S. F., \& Qosimov, L. M. (2021). Direction of modern design activities. Asian Journal of Multidimensional Research (AJMR), 10(2), 11-18. 